\title{
Synthesis of some new cyanopyrans and cyanopyridines and their biological activities
}

\author{
K. H. Popat, V. V. Kachhadia, Kiran S. Nimavat and H. S. Joshi* \\ Department of Chemistry, Saurashtra University, Rajkot-360 005, India \\ E-mail : drhsjoshi@yahoo.com_Fax:91-0281-2578512 \\ Manuscript received 31 January 2003, revised 12 May 2003, accepted 24 July 2003
}

\begin{abstract}
Chalcones 1-aryl-3-m-chlorophenyl-2-propene-1-ones, 1a-j, underwent Michael addition on refluxing with malononitrile in the presence of pyridine and ammonium acetate in ethanol to give compounds 2 -amino-3-cyano-4-( $3^{\prime}$-chlorophenyl)-6-(4-phenyl)-pyran, 2a-j and 2-amino-3-cyano-4-(3'-chlorophenyl)-6-(4-phenyl)-pyridine, 3a-j, respectively. The newly synthesized compounds have been screened for their anticancer, antitubercular and antimicrobial activities.
\end{abstract}

Biological activities of several heterocyclic analogues of chalcones have been reported in the literature ${ }^{1}$. There is a considerable interest in the chemotherapeutic activity of pyridine and pyran nuclei bearing carbonitrile group ${ }^{2}$. Chalcones are used to synthesize 2-amino-3-cyanopyran/ pyridine derivatives ${ }^{157}$. In the present study, we have followed this strategy for the synthesis of these compounds with the hope that they may possess different biological activities.

The chalcones (1a-j) were prepared from the reaction of benzaldehyde with different substituted aryl methyl ketones, in the presence of aqueous sodium hydroxide in the molar ratio $(1: 1)$. Condensation of chalcones $(\mathbf{1 a - j})$ with malononitrile in pyridine afforded corresponding pyrans (2aj). While chalcones (1a-j) were condensed with malononitrile and ammonium acetate in ethanol to give the corresponding pyridines (3a-j).

IR spectrum of (2a-j) and (3a-j) was in well agreement to the assigned structure, showing the absence of sharp band of carbonyl group and appearance of the sharp bands in the region of $3250-3400 \mathrm{~cm}^{-1}$ due to $-\mathrm{NH}_{2}$ group and in the region of $2200-2300 \mathrm{~cm}^{-1}$ due to $-\mathrm{C} \equiv \mathrm{N}$ group.

Disappearance of ${ }^{1} \mathrm{H}$ NMR signals for $-\mathrm{CH}=\mathrm{CH}$ - and appearance of signal for $-\mathrm{NH}_{2}$ between $\delta 8$ to 9.5 for structure (2a-j) and (3a-j) indicates cyclisation of (1a-j) to (2aj) or (3a-j).

The structures of the synthesized compounds were assigned on the basis of elemental analyses, IR, ${ }^{1} \mathrm{H}$ NMR and mass spectral data. The compounds were screened for their in vitro anticancer, antitubercular and antimicrobial activities.

The anticancer screening of some selected compounds was carried out at National Cancer Institute, Department of Health and Human Service, Bethesda, U.S.A. The study is related with in vitro anticancer screen aimed at identifying agents having cell type specificity using batteries of cell lines derived from human solid tumors. At its primary anticancer assay, a 3-cell panel consisting of NCI-H 460 (Lung), MCF7 (Breast) and SF-268 (CNS) has been used. A $48 \mathrm{~h}$ continuous drug exposure protocol is used, and a sulforhodamine $\mathrm{B}$ (SRB) protein assay is used to estimate cell viability or growth $^{4}$.

Comparing the known structure activity relationship, compounds $3 \mathbf{e}$ and $\mathbf{3 g}$ have been selected for the primary anticancer screening.

The antitubercular evaluation of the compounds was carried out at Tuberculosis Antimicrobial Acquisition Coordinating Facility (TAACF), U.S.A. Primary screening of the compounds for antitubercular activity has been conducted at minimum inhibition concentration $6.25 \mu \mathrm{g} / \mathrm{ml}$ against Mycobacterium tuberculosis $\mathrm{H}_{37} \mathrm{R} v$ in BACTEC 12B medium using the ALAMAR radiometric system. The antimycobacterial activity data were compared with standard drug Rifampin at $0.25 \mu \mathrm{g} / \mathrm{ml}$ concentration, which showed 98\% inhibition. Compounds having 4-bromo, 4-methyl, 2hydroxy, 4-methyl and 4-bromo showed higher activity than the others.

The antimicrobial activity was assayed by using the cupplate agar diffusion method ${ }^{5}$ by measuring the zone of inhibition in $\mathrm{mm}$. All the compounds were screened in vitro for their antimicrobial activities against varieties of bacterial strains such as $E$. coli, $P$. vulgaris, B. megaterium, S. aureus and fungi $A$. niger at $40 \mu \mathrm{g} / \mathrm{ml}$ concentration. Standard drugs like amoxycillin, ampicillin, cipofloxacin, erythromycin and griseofulvin were used for the comparison purpose. It could 
be observed that compounds 1e (20), 1f (19), 2h (17), 3b $(21)$ and $3 f(18)$ were active against $E$. coli. Compounds 1c (22), $2 \mathbf{e}(19), \mathbf{2 i}(19), \mathbf{3 b}(22)$ and $\mathbf{3 d}$ (20) were active against P. vulgaris. Compounds 1g (19), 2f (20), 3a (19), 3d (20) and $3 \mathrm{~g}(19)$ were active against $B$. mega. Compounds $1 \mathrm{c}$ (19), 2b (20), 2f (20), 3a (21) and 3h (26) were active against $S$. aureus. The compounds $\mathbf{1 g}(18), \mathbf{2 g}(20)$ and $\mathbf{3 j}$ (17) displayed maximum activity against $A$. niger.

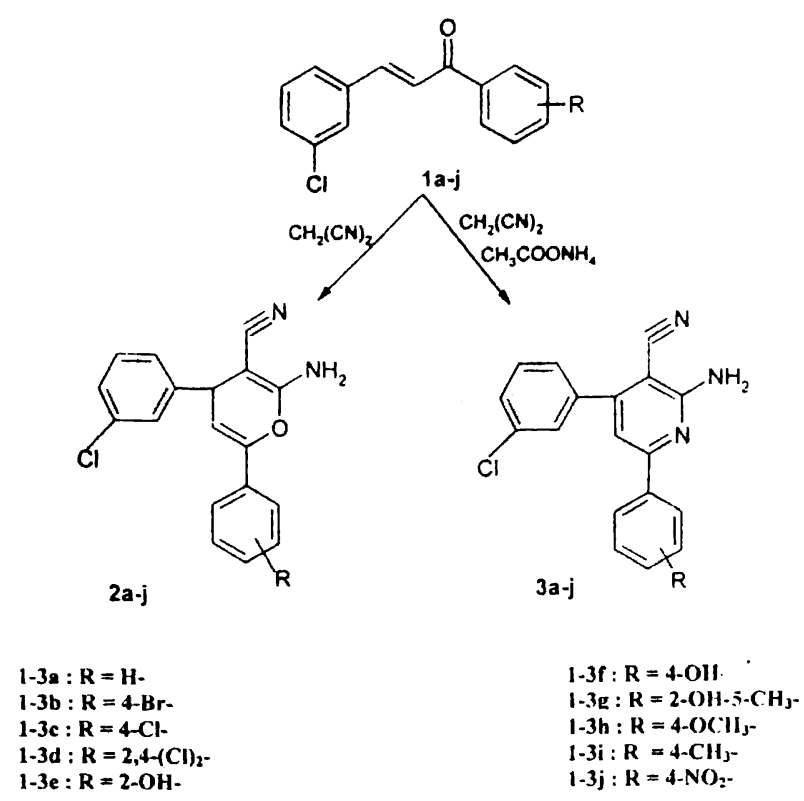

Scheme 1

\section{Experimental}

TLC was used to access the reactions and purity of the compounds synthesized. All m.ps. are uncorrected. IR spectra were recorded on Shimadzu FTIR-8400 instrument in $\mathrm{KBr}$ disc. ${ }^{1} \mathrm{H}$ NMR spectra were recorded on Bruker AC$300 \mathrm{MHz}$ FT NMR using TMS as an internal standard, chemical shift in $\delta$ ppm. Mass spectra were recorded on Jeol D-300 spectrometer. All the compounds gave satisfactory elemental analyses.

1-(4-Methoxy phenyl)-3-(3'-chlorophenyl)-2-propen-lone (1h) :

An ethanolic solution of 3-chlorobenzaldehyde (1.41g, $0.01 \mathrm{~mol}$ ) and 4-methoxy acetophenone $(1.50 \mathrm{~g}, 0.01 \mathrm{~mol})$ in presence of catalytic amount of $30 \% \mathrm{KOH}$ was stirred for $24 \mathrm{~h}$ at RT. The resulting solution was then poured over crushed ice, isolated and crystallized from ethanol to give Ih, $\left(88 \%\right.$ ), m.p. $95^{\circ}$ (Found : C, 70.56; H, 4.70. Requires for $\left.\mathrm{C}_{16} \mathrm{H}_{13} \mathrm{O}_{2} \mathrm{Cl}: \mathrm{C}, 70.59 ; \mathrm{H}, 4.78 \%\right) ; v_{\max } 3044(\mathrm{CH}=\mathrm{CH}$, vinyl), $2996\left(\mathrm{CH}_{3}, \mathrm{sym}\right.$ ), $1676(\mathrm{C}=\mathrm{O}), 1259 \mathrm{~cm}^{-1}(\mathrm{C}-\mathrm{O}-$ C); $\delta 3.89\left(3 \mathrm{H}, \mathrm{s}, \mathrm{OCH}_{3}\right), 7.26(1 \mathrm{H}, \mathrm{d}, \mathrm{CH}=\mathrm{CH}), 7.73$ $(1 \mathrm{H}, \mathrm{d}, \mathrm{CH}=\mathrm{CH}), 6.97$ to $8.04(8 \mathrm{H}, \mathrm{m}, \mathrm{Ar}-H) \mathrm{ppm} ; \mathrm{m} / \mathrm{z}$ 272.5 .

Similarly other compounds : 1a, m.p. $70^{\circ} ; \mathbf{b}, 70^{\circ} ; \mathbf{c}$, $100^{\circ} ; \mathbf{d}, 108^{\circ} ; \mathbf{e}, 120^{\circ} ; \mathbf{f}, 71^{\circ} ; \mathbf{g}, 135^{\circ} ; \mathbf{h}, 95^{\circ} ; \mathbf{i}, 80^{\circ} ; \mathbf{j}, 124^{\circ}$ (yields $62-88 \%$ ) were prepared.

Preparation of 2-amino-3-cyano-4-(3'-chlorophenyl)6-(4-methoxy phenyl)-pyran (2h):

A mixture of $1 \mathrm{~h}(2.72 \mathrm{~g}, 0.01 \mathrm{~mol})$ and malononitrile $(0.66 \mathrm{~g}, 0.01 \mathrm{~mol})$ dissolved in pyridine $(20 \mathrm{ml})$ was heated under reflux for $10 \mathrm{~h}$ in oil bath. The reaction mixture was cooled and poured over crushed ice. The product was isolated and crystallized from ethanol to give $\mathbf{2 h}$, (76\%), m.p. $270^{\circ}$ (Found : C, 67.45; H, 4.42; N, 8.26. Requires for $\left.\mathrm{C}_{19} \mathrm{H}_{15} \mathrm{~N}_{2} \mathrm{OCl}: \mathrm{C}, 67.45 ; \mathrm{H}, 4.43 ; \mathrm{N}, 8.28 \%\right) ; v_{\max } 3284$ $(\mathrm{N}-\mathrm{H}), 2219(\mathrm{C} \equiv \mathrm{N}), 1613(\mathrm{C}=\mathrm{C}), 1254 \mathrm{~cm}^{-1}(\mathrm{C}-\mathrm{O}-\mathrm{C}) ; \delta$ $3.90\left(3 \mathrm{H}, \mathrm{s}, \mathrm{OCH}_{3}\right), 4.67(1 \mathrm{H}, \mathrm{d}, \mathrm{CH}$-pyran ring), 7.01 to $7.96(9 \mathrm{H}, \mathrm{m}, \mathrm{Ar}-\mathrm{H}+\mathrm{py}-\mathrm{H}), 8.58\left(2 \mathrm{H}, \mathrm{s}, \mathrm{NH}_{2}\right) \mathrm{ppm} ; \mathrm{m} / \mathrm{z}$ 338.

Similarly other compounds : 2a, m.p. $300^{\circ} ; \mathbf{b}, 210^{\circ}$; c, $273^{\circ} ; \mathbf{d}, 192^{\circ} ; \mathbf{e}, 280^{\circ} ; \mathbf{f}, 216^{\circ} ; \mathbf{g}, 190^{\circ} ; \mathbf{h}, 270^{\circ} ; \mathbf{i}, 190^{\circ} ; \mathbf{j}$, $198^{\circ}$ (yields 58-78\%) were prepared.

Preparation of 2-amino-3-cyano-4-(3'-chlorophenyl)6-(4-methoxy phenyl)-pyridine (3h) :

A mixture of $1 \mathbf{h}(2.72 \mathrm{~g}, 0.01 \mathrm{~mol})$, malononitrile $(0.66$ $\mathrm{g}, 0.01 \mathrm{~mol})$, ammonium acetate $(6.61 \mathrm{~g}, 0.08 \mathrm{~mol})$ dissolved in ethanol $(20 \mathrm{ml})$, was heated under reflux for $12 \mathrm{~h}$. The product was isolated and recrystallized from ethanol, 3h (87\%), m.p. $150^{\circ}$ (Found : C, 68.24; H, 4.15; N, 12.50. Requires for $\mathrm{C}_{19} \mathrm{H}_{14} \mathrm{~N}_{3} \mathrm{OCl}: \mathrm{C}, 68.26 ; \mathrm{H}, 4.19 ; \mathrm{N}, 12.53 \%$ ); $v_{\max } 3219(\mathrm{~N}-\mathrm{H}), 2208(\mathrm{C} \equiv \mathrm{N}), 1602 \mathrm{~cm}^{-1}(\mathrm{C}=\mathrm{C}$ pyran $) ; \delta$ $3.88\left(3 \mathrm{H}, \mathrm{s}, \mathrm{OCH}_{3}\right), 7.79$ (1H, s, CH-pyr.), 6.98 to 8.02 $(8 \mathrm{H}, \mathrm{m}, \mathrm{Ar}-\mathrm{H}), 8.64\left(2 \mathrm{H}, \mathrm{s}, \mathrm{NH}_{2}\right) \mathrm{ppm} ; \mathrm{m} / z 335$.

Similarly other compounds : 3a, m.p. $180^{\circ}$; b, $202^{\circ}$; c, $265^{\circ}$; d, $185^{\circ}$; e, $268^{\circ} ; \mathbf{f}, 197^{\circ} ; \mathbf{g}, 215^{\circ}$; h, $150^{\circ} ; \mathbf{i} .160^{\circ} ; \mathbf{j}$, $280^{\circ}$ (yileds $55-69 \%$ ) were prepared.

\section{Acknowledgement}

The authors are thankful to Professor and Head, Department of Chemistry, Saurashtra University, Rajkot for facilities and encouragement, and also thankful to National Cancer Institute, U.S.A. and TAACF, U.S.A. for providing data of anticancer and antitubercular screening respectively. 


\section{References}

1. Masered Bernard, Wouters Johan, Pochet Lionel and Lambert Didier, J. Med. Chem., 1998, 41, 3235 (Chem. Abstr., 1998, 129, 202846).

2. Dyachenko, V. D. Litvinov and V. P. Russ, J. Org. Chem., 1998, 34, 554. (Chem. Abstr., 1999, 130, 223222).
3. A. Sakari and H. Midorikawa, Bull. Chem. Soc. Jpn., 1968, 41, 430 (Chem. Abstr., 1968, 69, 18985).

4. P. Skehan, R. Scudiero et al., J. Natl. Cancer Inst., 1990, 82, 1107.

5. A. L. Barry, "The Antimicrobial Susceptibility Test : Principle and Pactices", ed. Illuslea and Febiger, Philadelphia. U.S.A., 180 (Biol. Abstr., 1977, 64, 25183). 